338.1

A 7 ma

\section{STATE DOCURELITS}

JUN 11.1976

Montana Agrigultural Products

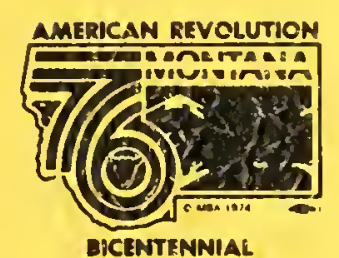

Montana Department of Agriculture

GEORGE LACKMAN

DI RECTOR 


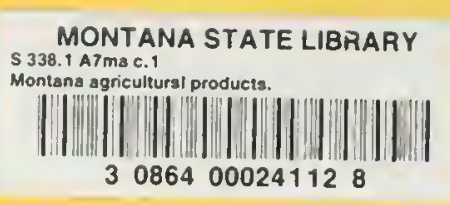




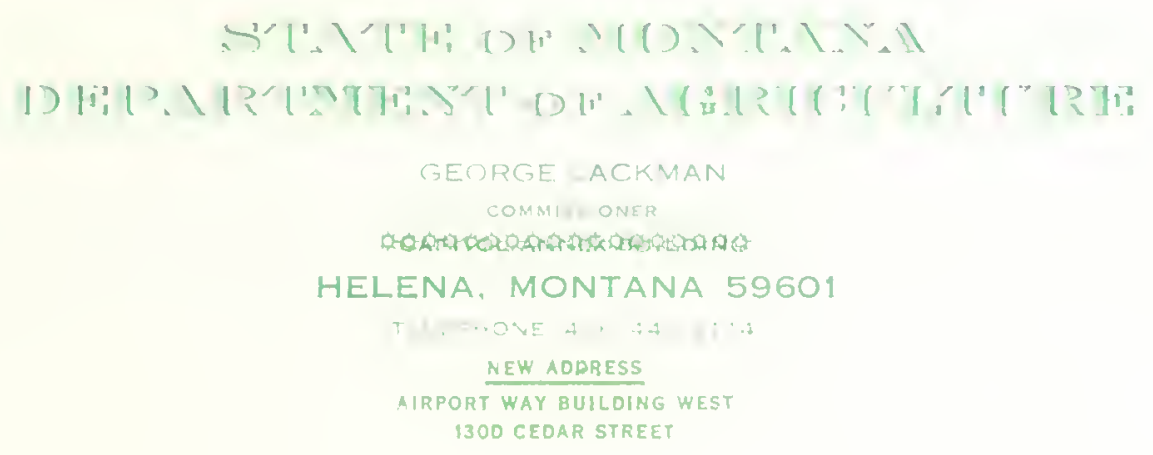

MONTANA AGRICULTURE

Montana agriculture of today is an example of progressive change and applied technology. It has both a proud heritage, as depicted in the works of artist C. M. Russe11, and a great potential for the future. This enormous potential is rivaled only by the enormity of our natural beauty, and will benefit the economic and social well being of Montana as it assures an increasingly more important role in supplying the demands of international markets.

Montana produced $120,108,000$ bushels of wheat in 1974. The total wheat production consists of $78,175,000$ bushels of winter wheat, 36,060,000 spring wheat and 5,073,000 durum. Barley production reached $37,120,000$ bushels. The oat crop produced $8,800,000$ bushels, and our flax seed production was 152,000 bushels. In addition, Montana produced $3,000,000$ pounds of alfalfa seed, $175,000,000 \mathrm{c} . \mathrm{w} . \mathrm{t}$. of potatoes and $154,000 \mathrm{c} . w . t$. of dry beans.

Montana stockmen had $3,340,000$ cattle and calves on hand January 1 , 1975. This cattle inventory was valued at $\$ 534,400,000$. The 770,000 sheep and lambs on Montana ranches and farms were valued at \$23 million. Hogs and pigs were estimated at 190,000 head at the end of 1974 . Total value of the swine inventory was $\$ 855,000$. In number of 1 ivestock among all of the states, Montana ranks 10 th in a 11 cattle and calves, 8 th in beef cows, 6 th in sheep and 29 th in hogs.

Agriculture is Montana's largest industry. It is also our fastest growing industry. Cash receipts to Montana agricultural producers have more than doubled in the past ten years; from slightly over $\$ 400$ million in 1964 to $\$ 1,190,403,000$ in 1974 . Better prices account for some of this growth, however, significant yield increases for most crops and increases in livestock production contributed importantly to this growth. 

The future potential of Montana agriculture is Miptesolv We have land and water resources available to expand curent prodistion, to develop thousands of acres of new irrigated crop lind, to producc a wide range of new crops, and to develop new agricultural product processing industries. Realization of this potential production is dependent upon effective marketing.

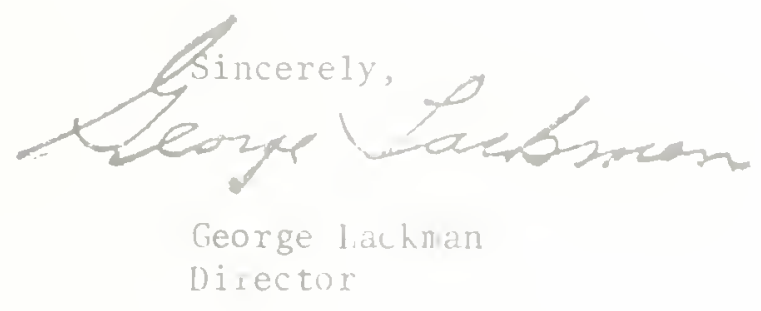



Wheat and barley production has long been known as Montana's "golden bonanza". Montana has a historic average annual production of 100 million-plus bushels of high protein, hard spring and winter wheat with some durum.

Normally, total production is composed of 50 to 55 million bushels of winter varieties, 40 to 50 million bushels of spring varieties, and approximately 5 million of durum. Barley production averages between 50 and $60 \mathrm{milli}$ ion bushels, which includes both quality livestock feed and malting types. A special note should be made in that winter varieties in 1974 increased to $78,000,000$ bushels and $108,000,000$ is projected for 1975 .

With the availability of suitable crop lands, resulting from changes in the United States farm policy and change in "summer fallow" cropping patterns, Montana's grain production could be expanded by" some 40 million bushels on a short term basis. Such expanded production could be in winter wheat, spring wheat, feed barley, or malting barley, dependent upon the demand of the market.

A11 sections of the international grain trading and miling industry are knowledgeable of the quality of Montana wheat and barley. Over last year, our Dark Northern Spring had a test weight of 60 plus pounds, with $15.4 \%$ protein. Dark Hard Winter testing showed a test weight of 61.9 pounds with $13.1 \%$ protein. Quality characteristics of Montana feed barley include high protein and freedom from molds and fungi. In addition, much of our production is of two row varieties which are larger seeded and therefore favored as livestock feed. Malting barley as grown in our high dry climate is of superior color, has plump kernels and low protein; all of which are viewed as desirable factors by maltsters.

In recent years approximately 70 percent of Montana's wheat production has entered the international export market with the Asian Rim being the major market area. In the case of barley, it is estimated that approximately 30 percent of our annual production is shipped out of Montana of which a portion enters export channels.

BEEF

Montana is frequently depicted as a mountain meadow with a herd of quality cattle peacefully grazing in lush grass. This picture is not just beautiful but is a common scene, for as the table shows there are $3,340,000$ head of cows spread over millions of acres of rangeland. The larger beef herd, which ranks eighth in the nation, produced $1,660,000$ calves in 1975 . 
It is important to note that while the state has large cattle numbers, the Montana beef industry has for many years been recognized for its leadership in producing superior quality animals. This reputation for superior purebred breeding stock, choice type of feeder cattle, and high quality commercial herds is not an unsupported claim based on just having large numbers. The industry and its representative agencies have always been and continue to be innovators in disease eradication programs, performance indexing, artificial insemination, and purebred herd development.

Montana has the most stringent quarantine regulations and strongest disease control authority in the United States. Livestock health officials, with the support of the industry, initiated scabies control programs in the early 1900's, recognized and pursued brucellosis eradication, and conducted control programs for bovine tuberculosis. These programs and others like them have provided Montana cattle with "scabies free", "brucellosis free", "bovine tuberculosis free" designations and an excellent overall heal th reputation.

For nearly fifty years the Montana beef performance indexing associations have tested the heritability of economic traits of beef cattle. This program selects breeding stock which are genetically superior in the feedlot and in carcass quality. Montana beef herds now have a higher percentage of performance indexed individuals than any state in the nation. It is natural that with the index information on superior sires and the availability of such sires or their semen artificial insemination is incorporated in herd improvement projects to a greater degree than in most other areas.

The "premium" of purebred seed stock beef cattle of the United States are in Montana. In the last two years our breeders have been the number one producer of quality purebred seed stock in the nation and the world. In the past few years the National Steer Champion, the National Champion Polled Hereford Bull, the National Champion Polled Hereford Heifer and the National Champion Shorthorn Bull came from Montana. People from all over the United States and the world have come to recognize Montana for premium Charolois, Angus, Hereford, Polled Hereford, Shorthorn, Simmental, Maine Anjou, and Limousin cattle.

Over 500 Angus breeders, 250 Polled Hereford breeders, 92 Shorthorn breeders, 185 Charolois breeders, and 562 Horned Hereford breeders, registered over 47,000 calves in 1973. In addition to these breeds the following exotic breeds have been added to provide the buyer an expanded selection; Murray Grey, Chianina, Simmental, Maine Anjou, Limousin, Tarentaise, and Blonde d'Aquitaine. This level of production provides the buyer tremendous opportunity for selection. 
Montana ranchers have traditionally supplied quality feeder cattle to other feeding areas throughout the country. Out-of-state shipments of feeder animals total approximately one million head each year. This market pattern is changing as more interests recognize the availability of the basic needs: available feed grains, quality feeder cattle, desirable climate, good locations; and the economic potential of cattle feeding within the state.

The number of cattle placed in feedlots has more than doubled over the last twelve years, 112,000 head in 1963 to an average of 200,000 head per year over the last four years. This increase in cattle fed reflects a growth in the size and the number of feedlot facilities. A part of this growth is the expansion of facilities available to feed cattle on a custom contract basis.

Montana barley production averages approximately $50 \mathrm{million}$ bushels per year. Of this production some 30 percent is shipped out-of-state for utilization. With these major resources available there is no area in the United States which offers more potential for growth in cattle feeding than Montana.

The Montana beef industry includes modern paching plants which can process the beef to sides, loins, and special cuts for direct shipment to overseas markets. So whether the need be for purebred cattle, quality commercial feeder cattle, contract custom feeding, sides of beef or processed beef, Montana is able to fulfill your requirements.

MONTANA BEEF

\begin{tabular}{lrrrrrrrrr}
\hline & 1969 & 1970 & $\frac{1971}{1972}$ & $\frac{1972}{1973}$ & $\underline{1974}$ & $\underline{1975}$ \\
\hline $\begin{array}{l}\text { Cattle and Calves } \\
\text { Inventory }\end{array}$ & 2,984 & 3,014 & 3,165 & 3,165 & 3,197 & 3,380 & 4,200 \\
$\begin{array}{l}\text { Calf Crop } \\
\text { Cattle on Feed }\end{array}$ & 1,508 & 1,535 & 1,582 & 1,630 & 1,730 & 1,725 & 1,660 \\
\end{tabular}

The Montana Livestock Export Center, located at the Helena Airport provides all services necessary for producers to export livestock to the world markets.

For more information contact: Montana Air Route International P.O. Box 403

Helena, Montana 59601 
Market hog production in Montana is a strong and growing industry. Its strength and aggressiveness is supported by a high level of management experience and substantial numbers of young producers, many of whom are college graduates, entering the industry on a permanent basis.

The Montana Pork Producers Council, a producer's organization, is active in helping these producers through education and market development projects. Efforts by the Council are serving the industry in achieving its full potential.

Montana has quality hogs and therefore produces superior pork carcasses. Data from the "National Barrow Show" and the "Montana NoIthern Intemational Livestock Exposition" provides a quantitative comparison of quality factors. The top 49 hogs at the national show compared to the top ten animals in the Montana competition is as follows:

\begin{tabular}{|c|c|c|}
\hline & National & Montan \\
\hline Inches of back fat & 1.20 & 1.18 \\
\hline $\begin{array}{l}\text { Square inches of } \\
\text { loin eye }\end{array}$ & 5.48 & 5.29 \\
\hline Percent of ham & 16.0 & 17.1 \\
\hline
\end{tabular}

In addition, 85 percent of four full loads of hogs in a recent carcass project were in U.S. Grades 1 and 2, which is above average quality.

Pork production in Montana is increasing. From 1950 to 1965 the pig crop fluctuated around 250,000 head per year. From 1969 to 1973 the pig crop ranged from 319,000 to a high of 430,000 in 1971 to 30) 1,000 in 1974 .

Approximately one-half of the 301,000 hogs produced in Montana in 1974 were shipped out-of-state, either live or as pork. It requires about 226,000 hogs to produce the pork consumed in the state each year. Due primarily to the marketing structure of United States supermarkets, a large portion of this local demand is supplied by processed pork imported from Midwest sources. Thus, Montana is in a solid net export position able to serve new markets.

New varieties of barley are being developed by the Montana Agricultural Experiment Station which are more efficient and require less supplements for hog rations. Tests in several of the new varieties have exhibited improved growth and efficiency in pigs. Such new technologies in association with Montana's barley production, which averages (1) million bushels per year, provide an excellent input resource base 
for substantial increase in pork production and processing. Estimates by Pork Council personnel are; if returns to resources are such that one-half of the barley now shipped out-of-state were to be utilized in hog production, Montana could produce some 1,000,000 hogs for processing annually.

The hog slaughtering facilities in the state include moderm, wellequipped, federally-inspected plants with varying capacities. Fleven of the 28 federally inspected slaughter plants in Montana indicate a capacity of processing 2,800 more hogs per week at current levels of production. Many of these facilities which are of a smaller size are capable and interested in slaughtering hogs on a custom basis, giving attention to special requirements needed in cutting pork specifically for the foreign markets.

The Montana pork industry has steadily increased its production of quality hogs to a level which can supply additional export markets on a continuing basis. Further, the producer's interest through their associations in market development and experience in coordinating the purchasing, processing and selling of pork provides a unique flexibility, within the market structure, to supply the growing demand for pork.

SHEEP

Montana's sheep hold a distinct advantage over those produced in most of the other states principally because of its dual purpose breeds. The greater majority of Montana's sheep are of the white-face breeds which produce high quality wool that is very much in demand, and also produce a very acceptable feeder lamb for delivery to feeding operations.

The average ewe produces ten pounds of wool per year and at least one $1 \mathrm{amb}$. This total production of $6,444,000$ pounds of wool and 635,000 lambs in 1976 ranks Montana sixth nationally.

Like that of other states, Montana's sheep industry has experienced a measurable decline over the past ten years, with sheep numbers reflecting an approximate 46 percent decrease in the state. Increased use of synthetic fibers causing less demand for wool, restrictions on available range to graze sheep, increasing predatory animal problems have all had a causal effect on the decline of "rangeoriented" sheep production.

Montana's sheep industry is launching itself into a plan of performance -- testing its seed stock for use in commercial and purebred operation. They have introduced a system of performance -- testing in the annual "State Ram Sale" which markets over 500 of the top quality rams in the state each year. Other positive factors within the structure of the industry are increase in farm flock operations which are less affected by problems of predators and lack of large tracts of range; new breeds, with emphasis on multiple births are gaining acceptance with the industry, and growing interest in confinement and integrated systems to accelerate production. 
The Montana sheep industry can competitively serve the needs of the foreign markets for lamb products and the availability of established wool marketing pools, providing buyers direct access to substantial qualities of Montana wool.

HONEY

Montana is the largest producer of truly premium quality honey. Throughout the American honey industry, Montana is known as the very heart of mild-flavored, heavy-bodied, clover honey production. Presently, most commercial honey packers in the United States consider Montana honey to be of "too superior" quality to pack directly into consumer containers. It is used to blend with inferior flavored and high moisture honeys of other regions.

An average of 8 million pounds of delicate clover flavored honey, with very low moisture, is produced annually. The primary and predominate source of nectar are wild yellow sweet clover and alfalfa. The combination of the two floral sources are ideal for honey with the delicate clover "tang".

Quality statistics contained in the following chart show the average color rating and moisture content for Montana honey is significantly superior to the national average. The reliability and uniformity of quantities of honey in excess of one million pounds with "P fund" color gradings averaging $20 \mathrm{~mm}$ or less cannot be matched anywhere in the world.

MONTANA HONEY

\begin{tabular}{|c|c|c|c|}
\hline \multirow[b]{2}{*}{ Year } & \multicolumn{3}{|c|}{ Production } \\
\hline & Colonies & Yield Per Colony & Total \\
\hline 1969 & 77,000 & $1251 \mathrm{bs}$. & $9,625,000$ lbs. \\
\hline 1970 & 76,000 & 105 & $7,980,000$ \\
\hline 1971 & 74,000 & 55 & $4,070,000$ \\
\hline 1972 & 74,000 & 110 & $8,140,000$ \\
\hline 1973 & 75,000 & 102 & $7,650,000$ \\
\hline 1974 & 77,000 & 89 & $6,853,000$ \\
\hline 1975 & 75,000 & 97 & $7,275,000$ \\
\hline
\end{tabular}

QUALITY

Index

National Average

dark side of white

5.25
Montana Average

light half of extra white

2.0

() to 9 ( 1 ight to dark) 
Montana is one of the few states with major growth potential for honey production. Available uncultivated areas and increasing utilization of available water offers ideal sweet clover forage areas. With continued leadership in applying improved management practices, it is estimated that honey production can be increased by 36 percent within five to six years.

The structure of honey marketing consists of individual producers' direct sales and contact sales to out-of-state processors accounting for approximately 50 percent of the total. It is noteworthy that Montana has the first fully operational bulk honey handling facility. This operation is capable of supplying honey in tank truck and carload tanker lots of 45,000 to 110,000 pounds with further experience in unitized container shipments for export. This particular segment of the industry represents the remaining 50 percent of total marketings.

Montana's honey industry with its recognized quality, superiority, availability of supply, production potential and a marketing structure that is capable to readily serve the export market provides an excellent potential for new foreign and domestic trade.

\section{CERTIFIED SEED POTATOES}

Since 1972, Montana seed potato growers have succeeded in building and maintaining a certified seed program of unequaled caliber. The Montana Potato Improvement Association is responsible for supervising the program which consists of formulating rules and regulations pertaining to production of disease free seed potatoes. The Association is governed by a four-member Board of Directors which are elected from the Association membership. All certified seed growers are members of the Association.

The potatoes are grown in fertile valleys surrounded by towering mountains that reach to 11,000 feet. The growers not only enjoy the aesthetic value, but appreciate the isolation barriers provided by the mountains. For this reason, Montana has rarely experienced green peach aphid infestations. Russet Burbank predominates as the leading variety, with 4,602 acres certified in 1973. Norland, Norgold Russet, White Rose and LaSoda are certified varieties grown in lesser amounts.

In 1969 Montana expanded the certified program to grow seed potatoes free of latent viruses. Each field entered for virus free certifications undergoes rigid field and cellar inspections. Also, Leaf samples are collected and are processed under serological procedures. In 1970 there were 185 acres certified as latent virus free and this was increased to 1,664 acres in 1973. Results from this program are very favorable as growers have reported a ten to twenty percent yield increase and the incidence of blackleg in this stock is negligible. 


\begin{tabular}{|c|c|c|c|c|c|c|}
\hline \multirow[b]{2}{*}{ Year } & \multicolumn{3}{|c|}{ CERTIFIED SEED STOCK } & \multicolumn{3}{|c|}{ VIRUS FREE STOCK } \\
\hline & Acres & or & Hectares & Acres & or & Hectares \\
\hline 1969 & 4,293 & & 1,738 & $-0-$ & & $-0-$ \\
\hline 1970 & 4,783 & & 1,936 & 185 & & 75 \\
\hline 1971 & 5,512 & & 2,232 & 510 & & 206 \\
\hline 1972 & 4,871 & & 1,972 & 636 & & $25 ?$ \\
\hline 1973 & 4,613 & & 1,868 & 1,664 & & 674 \\
\hline $1976^{e}$ & 6,000 & & 2,429 & 3,000 & & 1,215 \\
\hline $1980^{f}$ & 20,000 & & 8,097 & 10,000 & & 4,048 \\
\hline
\end{tabular}

e-Current estimate 1976 season's production.

f-Projected short-term production response to new market demand.

The above table shows a steady growth in the total production of seed potatoes. However, of equal importance is that "total certified seed potato" acreage could be increased by four hundred percent over the next five years. With approximately $80 \%$ of the total certified potatoes currently exported as seed to other states, regions and countries, seed growers are familiar with an exportive market structure. The experience and immediate increased production capability together with a superior quality product are advantageous requisites for new export trade in the foreign market.

The foregoing material is designed as a preliminary introduction to areas of Montana agriculture and their potential to supply the foreign markets. This information is not totally inclusive. However, it is representative of existing potentials.

For further information, contact:

THE MONTANA DEPARTMENT OF AGRICULTURE

MARKETING AND TRANSPORTATION DIVISION

1300 CEDAR STREET

AIRPORT WAY BLDG. WEST

HELENA, MONTANA 59601

Special thanks are expressed to all of the Farm and Commodity Organizations representing Montana agriculture for their assistance in compiling this presentation. 


